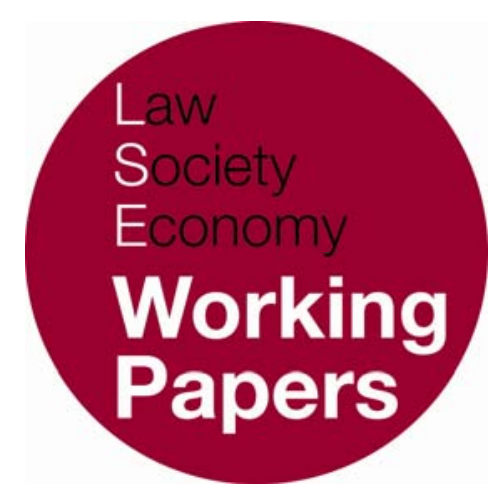

\title{
Courts and Conditions of Uncertainty in 'Times of Crisis'
}

\author{
Thomas Poole
}

LSE Law, Society and Economy Working Papers 7/2007 London School of Economics and Political Science Law Department

This paper can be downloaded without charge from LSE Law, Society and Economy

Working Papers at: www.lse.ac.uk/collections/law/wps/wps.htm and the Social Science Research Network electronic library at: http:/ / ssrn.comabstract $=1013503$

(C) Thomas Poole. Users may download and/or print one copy to facilitate their private study or for non-commercial research. Users may not engage in further distribution of this material or use it for any profit-making activities or any other form of commercial gain. 


\title{
Courts and Conditions of Uncertainty in 'Times of Crisis'
}

\author{
Thomas Poole*
}

\begin{abstract}
This paper examines recent decisions of the British courts in terrorism cases. Two general approaches are identified: the first seeks to accommodate government crisis-related claims; the second starts from the need to reassert 'normal' public law principles. The paper then explores the judicial response to a particularly important plane of argument - namely, questions of risk and uncertainty. While a number of different ways of responding to government arguments about risk are isolated, it is argued that it is ultimately better for the courts to confront these arguments directly in their judgments.
\end{abstract}

\section{INTRODUCTION}

In a speech given to the press but aimed at the courts, Tony Blair said that 'the rules of the game are changing. ${ }^{1}$ His sentiment captures the constitutional mood. We seem to have entered an era of 'aggressive constitutionalism' marked by the deployment, principally but not solely by government, ${ }^{2}$ of a 'crisis paradigm' according to which the threat we now face from 'international terrorism' 3 is of such novelty and magnitude that exceptional laws are required to deal with it. ${ }^{4}$

\footnotetext{
* Law Department, London School of Economics and Political Science. Earlier versions of this paper ('Peering through the Glass Darkly: Courts and Conditions of Uncertainty in Times of Crisis') were presented at seminars held at LSE on 17 January 2007 and at the University of Manchester on 26 February 2007. I would like to thank the participants at those seminars for their comments. I would also like to thank Julia Black, Carol Harlow, Gus van Harten, Nico Krisch, Martin Loughlin, Mike Redmayne and Gerry Simpson for their comments on a previous draft.

1 Tony Blair PM, speech of 5 August 2005.

2 See, e.g., Rehman v Secretary of State for the Home Department [2001] UKHL 47; [2003] 1 AC 153 at [62] (per Lord Hoffmann).

3 On the legal definition of 'terrorism' see C. Gearty, 'Terrorism and Human Rights: A Case Study in Impending Legal Realities' (1999) 19 Legal Studies 367, 371. On the definition laid down by the Terrorism Act 2000, see H. Fenwick, 'The Anti-Terrorism, Crime and Security Act 2001: A Proportionate Response to 11 September?' (2002) 65 MLR 724, 734.

${ }^{4}$ See, e.g., J. Steyn, 'Guantanamo Bay: The Legal Black Hole' (2004) 53 ICLQ 1; G. Neuman, 'Comment Counter-Terrorist Operations and the Rule of Law' (2004) 15 EJIL 1019; K. Scheppele, 'North American Emergencies: The Use of Emergency Powers in Canada and the United States' (2006) 4 Int J of Const Law 213.
} 
Although claims for exceptional powers are always difficult for courts to handle, ${ }^{5}$ specific features of the present situation further complicate the judicial inquiry. First, governments everywhere seem increasingly prone to call on emergency powers of one sort or another. Gross argues that the proclivity of governments in recent times to invoke emergency powers threatens to bring about the 'normalizaton of the exception': 'in various meaningful ways, the exception - the state of emergency and the concomitant "emergency regime" - has merged with the rule - the "normal" and "ordinary".' And, at the local level, Gearty observes that terrorism laws 'are becoming essential saviours of our society, safeguards against an otherwise inevitable barbarism: in short the new common sense of our age." ${ }^{7}$ Second, even if we accept that the terrorist threat is sufficient to create a state of exception, the ill-defined and continuing nature of that threat means that, even on the most optimistic assessment, ${ }^{8}$ we are faced with the prospect of an 'exceptional' situation that has no apparent limit. 'Terrorism' and 'counterterrorism' are 'repeat players' in a game that can have no clear end. This makes the 'war on terrorism' more like a condition than a war: 'more like the war on cancer, the war on poverty, or, most pertinently, the war on crime."

Some constitutional scholars doubt that the courts have the capacity to play a meaningful role in conditions of (putative) crisis. Political communities, Ackerman says, have embarked on a 'pathological political cycle' the result of which will be 'successive waves of repressive laws designed to ease our anxiety by promising greater security'. In this context, he argues, the traditional recourses of the constitutional lawyer - democracy and the courts - are inadequate, even problematic. Democracy is the 'root of the problem', since competitive elections tempt politicians 'to exploit the spreading panic to partisan advantage'. And courts 'haven't protected us in the past' in analogous situations, 'and they will do worse in the future.' ${ }^{10}$ Half-hearted judicial oversight may be worse than no judicial oversight at all. Dyzenhaus has argued that it is 'grey holes' rather than the 'black holes'11 that should concern us most. In other words, situations where legality

5 See, e.g., A.W.B. Simpson, In the Highest Degree Odious: Detention Without Trial in Wartime Britain (Oxford: OUP, 1992).

6 O. Gross, 'What “Emergency” Regime?' (2006) 13 Constellations 74, 85. Giorgio Agamben claims that the 'state of exception' is fast becoming the dominant paradigm of government in contemporary politics, 'a technique of government that threatens to alter - in fact, has already palpably altered - the structure and meaning of the traditional distinction between constitutional forms.' See State of Exception (Chicago: University of Chicago Press, 2005, 2. See also, e.g., U. Beck, Risk Society (Sage, 1992), 78-8: risk societies 'possess on the one hand the pretense of normality, and on the other, the enabling power of catastrophes ... The risk society is thus not a revolutionary society, but more than that, a catastrophic society. In it the state of emergency threatens to become the normal state.'

7 C. Gearty, Can Human Rights Survive? (Oxford: OUP, 2006), 102.

8 See, e.g., President Bush's State of the Union Address, Feb. 12006 in which the President describes 'the end of tyranny in our world' as being a 'long-term goal'.

9 M. Tushnet, 'Defending Korematsu? Reflections on Civil Liberties in Wartime' (2003) Wisconsin Law Review 273.

10 B. Ackerman, Before the Next Attack (New Haven: Yale University Press, 2006), 1-3. See also, e.g., K.D. Ewing, 'The Futility of the Human Rights Act' [2004] PL 829.

11 J. Steyn, 'Guantanamo Bay: The Legal Black Hole' (2004) 53 ICLQ 1. See also, e.g., R (Abbasi) v Secretary of State for Foreign and Commonwealth Affairs [2002] EWCA Civ 1598 (per Lord Phillips MR). 
does not operate at all will be rare. Governments are more likely to seek to create schemes in which there is the façade or form of the rule of law rather than any substantive legal protections.' ${ }^{\prime 2}$ If the obstacles that courts encounter when charged with applying or reviewing such schemes are such that anything more than a 'light touch' approach is precluded, then all that judges may be doing is plastering what Sullivan J has called a 'veneer of legality' over the exercise of exceptional powers. ${ }^{13}$

This article focuses on recent decisions of the domestic courts in cases involving counter-terrorist laws. One vital issue courts must address in these cases is what standard of 'deference'14 - or 'discretionary area of judgment' 15 - ought to be accorded to the executive. ${ }^{16}$ In addressing this point, two principles pull in opposite directions. The first is the duty of courts to protect civil liberties and human rights, a duty now reinforced and mandated by the Human Rights Act. As Simon Brown LJ has said, the 'court's role under the Human Rights Act is as the guardian on human rights. It cannot abdicate this responsibility.' 17 The second is that courts should recognise the legitimacy of the government's authority to act in the interests of national security. It is almost axiomatic within the context of judicial review that 'the executive is better placed that the judiciary' when it comes to the 'evaluation of intelligence about a national security issue'. ${ }^{18}$

The article examines in particular the way domestic courts have approached the apparent conflict between these two principles. The analysis reveals that the courts have not spoken with one voice. Rather, two general approaches are isolated: the first seeks to accommodate government crisis-related claims, whereas the second starts from the need to reassert 'normal' public law standards. The article then explores the judicial response to a particularly important plane of argument: namely, questions of risk and secrecy. These questions may be regarded as 'conditions of uncertainty' that beset judicial decision-making in this context. By highlighting these conditions, my aim will be to identify a number of different ways of responding to government arguments about risk, arguing that ultimately it

${ }^{12}$ D. Dyzenhaus, The Constitution of Law: Legality in a Time of Emergency (Cambridge: CUP, 2006), 3.

13 Secretary of State for the Home Department v MB [2006] EWCA Civ 1140 at [27]. Cf Tushnet, n 9 above: emergency powers 'provide executive officials with a feg-leaf of legal justification for expansive use of sheer power.'

14 J. Jowell, 'Judicial Deference and Human Rights: A Question of Competence' in P. Craig and R. Rawlings (eds.), Law and Administration in Europe (Oxford: OUP, 2003); M. Hunt, 'Sovereignty's Blight: Why Contemporary Public Law Needs the Concept of "Due Deference" in N. Bamforth and P. Leyland (eds.), Public Law in a Multi-Layered Constitution (Oxford: Hart Publishing, 2003); R. Clayton, Judicial Deference and Democratic Dialogue: the Legitimacy of Judicial Intervention under the Human Rights Act 1998' [2004] PL 33. See also, e.g., R v DPP, exp Kebilene [2000] 2 AC 326 at 381 (Lord Hope); R v Lichniak [2002] UKHL 47; [2003] 1 AC 903 at 912A (Lord Bingham).

15 Lord Steyn, 'Deference: A Tangled Story' [2005] PL 346, 350. CfLord Hoffmann in R (ProLife Alliance) v BBC [2003] UKHL 23; [2004] 1 AC 185 at [75]: 'although the word "deference" is now very popular in describing the relationship between the judicial and the other branches of government, I do not think that its overtones of servility, or perhaps gracious concession, are appropriate'.

16 See L. Zedner, 'Securing Liberty in the Face of Terror: Reflections from Criminal Justice' (2005) 32 JLS 507, 525-9.

${ }_{17}$ International Transport Roth GmbH v Secretary of State for the Home Department [2002] EWCA Civ 158; [2003] QB 728 at [27] (per Simon Brown LJ).

${ }^{18}$ Steyn, $\mathrm{n} 15$ above, 349. 
is better for the courts directly to respond to the conditions of uncertainty in their judgments.

\section{THREE MODELS OF 'CRISIS CONSTITUTIONALISM'}

The UK has traditionally operated a political ${ }^{19}$ or parliamentary ${ }^{20}$ constitution, one effect of which has been that law has played 'only an intermittent role in delimiting executive power and holding its exercise to account.'21 Judicial reluctance to intrude into the province of the executive ${ }^{22}$ has typically been heightened in the national security context, where courts have tended to treat national security as 'the exclusive responsibility of the executive'. ${ }^{23}$ As Lord Parker said in The Zamora, 'those who are responsible for the national security must be the sole judges of what the national security requires'. ${ }^{24}$ Although that case was decided in World War I, it has set the tone for peacetime cases. In Chandler $v$ DPP, for instance, in ruling that the statutory wording 'interests of the state' was synonymous with the government's conception of national security, the House of Lords emphasised that 'the disposition and armament of the armed forces are and for centuries have been within the exclusive discretion of the Crown'. ${ }^{25}$ National security is 'par excellence a non-justiciable question', ${ }^{26}$ Lord Diplock said in the CCSU case, unless the minister responsible can be shown to have acted otherwise than in good faith. ${ }^{27}$ The current authors of de Smith accept that the paucity of the judicial inquiry in these cases is such that national security claims are 'effectively unsupervised by the courts'. ${ }^{28}$

To what extent does this habit of judicial subservience to national security claims continue? Gross and Ní Aoláin identify three models of the way in which legal orders respond to acute crises. ${ }^{29}$ The first is the model of accommodation which countenances 'a certain degree of accommodation for the pressures exerted on the state in times of emergency, while, at the same time, maintaining normal legal

19 J.A.G. Griffith, 'The Political Constitution' (1979) 42 MLR 1.

${ }^{20}$ T. Koopmans, Courts and Political Institutions: A Comparative View (Cambridge: CUP, 2003) ch. 2. See also S.E. Finer, V. Bogdanor and B. Rudden, Comparing Constitutions (Oxford: OUP, 1995) ch. 3.

${ }^{21}$ A. Tomkins, 'The Struggle to Delimit Executive Power in Britain' in P. Craig and A. Tomkins (eds.), The Executive and Public Law (Oxford: OUP, 2006) 51. See also T. Daintith and A. Page, The Executive in the Constitution (Oxford: OUP, 1999) 13 \& 26.

22 Exemplified by the self-denying test of 'Wednesbury unreasonableness': Associated Provincial Picture Houses

v Wednesbury Corporation [1948] 1 KB 223.

${ }^{23} \mathrm{R} v$ Secretary of State for the Home Department, exp Cheblak [1991] 1 WLR 890 (per Lord Donaldson).

24 [1916] 2 AC 77, 107 (per Lord Parker).

${ }^{25}$ Chandler v DPP [1964] AC 763, 791 (per Lord Reid).

${ }^{26}$ Council of Civil Service Unions v Minister for the Civil Service [1985] AC 374, 412.

${ }^{27}$ Exp Cheblak, n 24 above (per Lord Donaldson).

28 S. de Smith, J. Jowell, A. Le Sueur, and H. Woolf, De Smith, Woolf and Jowell's Principles of Judicial Review (London: Sweet \& Maxwell, $5^{\text {th }}$ ed., 1995) 366-368.

${ }_{29}$ A classical - and historically influential - model is the Roman dictatorship: see, e.g., A. Lintott, The Constitution of the Roman Republic (Oxford: OUP, 1999) 109-115. Cf Agamben, n 6 above, ch. 3. 
principles and rules as much as possible. ${ }^{30}$ Ignatieff's recent book The Lesser Evil is illustrative. Ignatieff argues that democracies currently face a tragic choice. Fighting terrorism means that we cannot avoid doing evil acts altogether; the challenge is to choose lesser evils and to keep them from becoming greater ones. Calling for 'an ethics of prudence rather than first principle', he says that 'necessity may require us to take actions in defense of democracy which will stray from democracy's own foundational commitment to dignity. ${ }^{31}$ This model accepts that the exigencies of a crisis situation may require the reshaping or tailoring of existing constitutional and legal arrangements. Since it accepts that powers expand and rights contract (but are not necessarily suspended) in times of crisis, ${ }^{32}$ the model of accommodation also calls for a high degree of deference on the part of courts. ${ }^{33}$

The second model - 'Business as Usual' or 'Holding the Line' - rejects the need to introduce changes to the existing constitutional and legal system in crises and emergencies, and denies that there is always a tension between protecting security and maintaining basic values and rights. ${ }^{34}$ No special powers, general or ad hoc, are needed to deal with emergencies. ${ }^{35}$ Adhering to the principle fiat justitia ruat caelum, ${ }^{36}$ the model reflects a theory of 'constitutional absolutism'. ${ }^{37}$ As Aharon Barak, President of the Israel Supreme Court, has expressed it, 'Terrorism does not justify the neglect of accepted legal norms. This is how we distinguish ourselves from the terrorists themselves.' 38 A 'soft' variant of this model holds that constitutional rules must not be relaxed during times of crisis, but their outcomes may change. It accepts, in other words, that, in an emergency, 'the substantive content of what "reasonable" is may change'. (This variant thus operates as something of a mid-way position between this model and the model of accommodation.) The 'hard' variant holds the line more steadfastly, contending

30 O. Gross and F. Ní Aoláin, Law in Times of Crisis (Cambridge: CUP, 2006) 9.

${ }^{31}$ M. Ignatieff, The Lesser Evil (Princeton, NJ: Princeton University Press, 2004). See also, e.g., Ackerman, n 10 above.

32 See, e.g., Ex parte Milligan, 71 US (4 Wall.) 2, 141 (1866) (Chase, CJ, dissenting); R.H. Fallon, 'Individual Rights and the Powers of Government' (1993) 27 Georgia LR 343.

33 See, e.g., B. Ackerman, 'The Emergency Constitution' (2004) 113 Yale LJ 1029, 1066-777. At its furthest extreme, this approach may even flirt with the idea of judicially-mandated 'torture warrants': see, e.g., A. Dershowitz, 'Torture without Visibility and Accountability is Worse than With It' (2003) 6 U Penn J of Const Law 326.

34 See, e.g., D. Lublan, 'Eight Fallacies about Liberty and Security' in R.A. Wilson (ed.), Human Rights in the 'War on Terror' (Cambridge: CUP, 2005); J. Waldron 'Security and Liberty: The Image of Balance' (2003) $11 \mathrm{~J}$ of Pol Phil 191.

${ }^{35}$ For a recent defence of this position in the British context, see D. Feldman, 'Human Rights, Terrorism and Risk: The Roles of Politicians and Judges' [2006] PL 364. See also n 16 above, 525: 'continuing adherence to the rule of law and defence of due process not only better protects cherished liberties; it also conveys an important message about our determination to uphold justice, even in the face of repeated terrorist attack.'

36 Literally, 'let justice be done should the sky fall'.

${ }^{37}$ O. Fiss, 'The War Against Terrorism and the Rule of Law' (2006) 26 OJLS 235. Cf Justice Scalia's dissent in Hamdi v Rumsfeld 542 US 507 at 579 (2004): 'Whatever the general merits of the view that war silences law or modulates its voice, that view has no place in the interpretation and application of a Constitution designed precisely to confront war and, in a manner that accords with democratic principles, to accommodate it.'

38 A. Barak, 'Foreword: A Judge on Judging - The Role of a Supreme Court in a Democracy' (2002) Harv LR 16. 
'that not only the ordinary constitutional rules ought not to change in times of emergency, but so too the nature of the substantive outcomes of their application to specific cases. ${ }^{3} 3$

A final model - the Extra-Legal Measures Model - shares with the accommodation model an acceptance that exceptional legal responses may sometimes be necessary to deal with emergencies, but insists instead that government in exceptional situations must act openly outside the normal legal order. 'Hard cases make bad law. Times of emergency make some of the hardest of cases. What the Extra-Legal Measures model attempts to do is keep the ordinary legal system clean and distinct from the dirty and messy reality of emergency so as to prevent, or at least minimize, the perversion of that system in search for answers to hard, exceptional cases.' 40 Going against the thrust of Lord Atkin's dissent in Liversidge $v$ Anderson, ${ }^{41}$ adherents of this model adopt Cicero's maxim inter arma silent leges. ${ }^{42}$ And they draw support from Locke's theory of the prerogative ${ }^{43}$ and Thomas Jefferson's liberal theory of emergency powers. ${ }^{44}$ Advocates of this model defend it on two grounds. Not only would the adoption of this approach mean that the 'normal' principles constitution remain untainted by the exigencies of crisis management, but it would also offer better protection. The record of both legislatures and courts in the past in the face of claims for emergency powers is little short of lamentable. ${ }^{45}$ This being so, the best strategy is to force governments to act openly in defiance of normal constitutional standards and to require that any action it takes in the course of dealing with the emergency are subject to the ex post consent of the legislature. While the maintenance of ' $a$ veneer of normality and legalities' facilitated by the other models 'allows citizens to avert their eyes and minds from the crude reality surrounding them,' the virtue of this model lies in its capacity to disconcert. It 'forces us to look to what may be the darkest corners of our national life.' 46

We can translate these models into the more familiar terminology of domestic public law. Courts dealing with questions of legality in 'crisis' situations will often be called upon to decide whether or not an exercise of power is reasonable. In so doing, they will need to make an assessment of the level of deference (or the appropriate scope of the area of discretionary authority) due to the decisionmaker. The models identified by Gross and Ní Aoláin represent contrasting ways of approaching these questions, offering different answers to the question: 'what,

\footnotetext{
${ }^{39} \mathrm{n} 30$ above, 89.

40 ibid 161.

${ }^{41}$ Liversidge v Anderson [1942] AC 206.

42 ('Amidst the clash of arms the laws are silent.') See, e.g., M. Tushnet, 'Controlling Executive Power in the War on Terrorism' (2005) 118 Harvard LR 2673.

${ }^{43}$ J. Locke, Second Treatise on Government (Cambridge: CUP, ed. P. Laslett, $2^{\text {nd }}$ ed., 1970), chapter XVII. See also P. Pasquino, 'Locke on King's Prerogative' (1998) 26 Political Theory 198.

${ }^{44}$ For the influence of Locke on the founding fathers, see T.H. Breen, The Lockean Moment (Oxford: OUP, 2001).

45 See, e.g., Ackerman, n 10 above; Simpson, n 5 above.

46 O. Gross, 'Chaos and Rules: Should Responses to Violent Crisis Always be Constitutional?' (2003) 112 Yale LJ 1011, 1127-8.
} 
in this context, is reasonable?'. The model of accommodation offers the executive at least a degree of deference. What is 'reasonable', on this account, is what is reasonable (on a weak version) generally in times of emergency or (on a stronger version) in the context of this particular emergency. The 'Business as Usual' approach insists that no (extra) deference be shown. The standards of reasonableness to be applied are those applicable in normal times. (Although the 'soft' variant of this approach would accept some tailoring in the application of these standards.) The Extra-legal Measures model, by contrast, entails that when courts are called upon to review exercises of 'crisis powers' they must defer entirely to the executive. (Although this apparently deferential position need not be made for deferential reasons. Most proponents of this model would regard the court's decision not to apply ordinary standards of review as a strategic choice aimed at preserving the integrity of the constitution while forcing politicians to face the reality of what they are doing.) Anything, in principle, may be reasonable: in a crisis situation the court's role is limited to a formal, public declaration to the effect that normal standards are being deviated from. What is reasonable is best judged after the event and in another (political) forum.

\section{THE CASES: ACCOMMODATION V BUSINESS AS USUAL}

A faultline runs through the recent judgments dealing with challenges to government decisions relating to terrorism. Some follow the old authorities granting the executive a wide area of discretion, while others reflect a new willingness to put limits on the exercise of executive power. In terms of our models, we seem to be witnessing a struggle between one approach that seeks to accommodate executive crisis-related demands and a second that equates with (one variant of) the 'Business as Usual' model.

\section{STRAND 1: DEFERENTIAL ACCOMMODATION}

The decision of the House of Lords in Rehman illustrates the deferential line. Rehman involved a challenge to a deportation order made on national security grounds. The House of Lords ruled in favour of the Home Secretary, holding that the Special Immigration Appeals Commission (SIAC) had taken too narrow a view of what could constitute a threat to national security. Since a 'very large element of policy'47 pervades the area, 'the executive is the best placed judge of the need for international co-operation to combat terrorism and counter-terrorism strategies. ${ }^{38}$ In a postscript, Lord Hoffmann made explicit the connection between the decision and contemporaneous events:

47 Secretary of State for the Home Department v Rehman [2001] UKHL 47, [17] (per L Slynn).

48 ibid., [28] (per L Steyn). 
the recent events in New York and Washington ... are a reminder that in matters of national security, the cost of failure can be high. This seems to me to underline the need for the judicial arm of government to respect the decisions of ministers of the Crown. It is not only that the executive has access to special information and expertise in these matters. It is also that such decisions, with serious potential results for the community, require a legitimacy which can be conferred only by entrusting them to persons responsible to the community through the democratic process. ${ }^{49}$

The Court of Appeal in both its Belmarsh and Torture Evidence decisions (both of which were overturned on appeal) adopted a similar approach. In the former case, Brooke LJ said that, unless 'one is willing to adopt a purist approach, saying that this country should be destroyed', he argued, 'it seems to me inevitable that the judiciary must be willing ... to put an appropriate degree of trust' in the executive. There comes a stage, he concluded, 'when judicial scrutiny can go no further'. ${ }^{50}$ In the latter, the Court held that neither common law nor the ECHR prevented the admission of evidence that may have been obtained through the use of torture overseas in proceedings before SIAC. Both majority judges accepted the exceptional nature of the situation. Pill LJ emphasised the Home Secretary's 'duty to safeguard national security', ${ }^{51}$ while Laws LJ's starting point was the 'possibility of indiscriminate murder committed by extremists who for want of evidence could not be brought to book in the criminal courts'.52 The Anti-Terrorism, Crime and Security Act - rushed through Parliament after September $11^{53}$ - reflected, the Court held, a 'reasonable balance' between the conflicting demands of security and liberty. ${ }^{54}$

Despite these decisions of the House of Lords, it is not clear that this highly deferential approach has yet reached its terminus. ${ }^{55}$ Gillan concerned the exercise of stop and search powers exercised by police under provisions of the Terrorism Act 2000.56 A journalist and a student were stopped and searched under these powers while on their way to protest peacefully against an arms fair in Docklands. The House of Lords rejected their challenge, despite the fact that at the time the authorisation for such searches covered the whole Metropolitan Police District

49 ibid [62]. Lord Hoffmann's dicta were cited with approval by the Canadian Supreme Court in Suresh v Canada (Citizenship and Immigration) [2002] 1 SCR 3.

50 A v Secretary of State for the Home Department [2002] EWCA Civ 1502, [87].

51 A v Secretary of State for the Home Department [2004] EWCA Civ 1123, [127].

52 ibid., [155].

53 A. Tomkins, 'Legislating Against Terror: The Anti-Terrorism, Crime and Security Act 2001'[2002] PL 205.

${ }^{54}$ n 51 above, [236].

55 See also, e.g., R (Gentle) v The Prime Minister [2006] EWCA Civ 1690, [38]: 'the fact that the right relied upon by the applicants, if it exists, would involve the courts in examining matters traditionally regarded as non-justiciable, is a factor militating against its existence.'

56 Terrorism Act 2000, s 44. 
and that such authorisations has been made continuously for successive periods since the Terrorism Act had come into force. Lord Scott ruled that 'an assessment of the reasonableness of the response [sc. the authorisation] requires an assessment of the degree of seriousness of the terrorist threat to which the auth was a response. This latter assessment will in most cases require some knowledge of the intelligence material on which the police and the Home Secretary relied when making their own assessment of that threat'. ${ }^{57}$

These decisions share a number of characteristics. They tend to be responsive to government claims that the exceptional nature of the terrorist threat demands special rules and a different attitude from judges who interpret them or review their application. While courts today rarely talk of non-justiciability, indicating in so doing both an implicit rejection of older lines of authority and a lack of interest in the Extra-Legal Measures model advocated by Gross and others, they do seem willing to accommodate executive needs ${ }^{58}$ by recognising a broad area of untrammelled executive discretion. The position tends to be justified pragmatically, ${ }^{59}$ and by arguments about the limits of law. ${ }^{60}$

\section{STRAND 2: BUSINESS AS USUAL?}

The most prominent case in which calls for a high degree of judicial deference are rejected is the House of Lords' decision in Belmarsh. The case involved a challenge to provisions which allowed for the indefinite detention of foreigners suspected of being terrorists. The House of Lords addressed two main issues. First, whether the government's derogation from the ECHR in respect of the challenged detention measures was lawful. (The government had invoked Art. 15, which makes provision for a state to derogate from certain Convention obligations in time of 'war or other public emergency threatening the life of the nation', in respect of the power to detain.) Second, whether the statutory provisions under which the claimants had been detained were compatible with the Convention. (Art. 15 prescribes that the measures taken in derogation from the Convention must be 'strictly required by the exigencies of the situation'. ${ }^{61}$ ) By an eight-to-one majority, the House of Lords struck down the derogation order and issued a declaration of incompatibility under the Human Rights Act 1998 s. 4 against the detention

${ }^{57} \mathrm{R}$ (Gillan) v Commissioner of Police for the Metropolis [2006] UKHL 12, [62].

58 See also K.D. Ewing, 'The Futility of the Human Rights Act' [200?] PL 829, which contains a critical analysis of some of the cases decided before the House of Lords' decision in Belmarsh.

${ }^{59}$ See, e.g., the Court of Appeal's rejection of the claimants' argument in the Torture Evidence case partly on account of the 'practical unreality' of imposing a duty to inquire into the interrogation methods of other states: n 51 above, [254] (per Laws LJ).

${ }^{60}$ Lord Phillips MR said in R (Abbasi) v Secretary of State for Foreign Affairs [2002] EWCA Civ 1598 at [106] that 'the court cannot enter the forbidden areas, including decision affecting foreign policy.' See also $R$ (Al Rawi) v Secretary of State for Foreign Affairs [2006] EWCA Civ 1279. Abbasi and Al-Rawi, however, are complicated cases which are by no means entirely deferential to government.

${ }^{61}$ See, e.g., J.F. Hartman, 'Derogation from Human Rights Treaties in Emergencies' (1981) 22 Harvard JIL 1. 
provisions. Whereas, for Lord Hoffmann, ${ }^{62}$ the government's argument fell at the first hurdle - there was, he argued, no public emergency threatening the life of the nation - the rest of the majority found against the government on the second (and less intrusive) ground that the challenged provisions were discriminatory and disproportionate. Indeed, there is a trace of schizophrenia to the majority's position. ${ }^{63}$ On the first issue, the majority granted the executive a very broad measure of discretion. Lord Bingham said that 'great weight' should be attached to the judgement of the Home Secretary and his colleagues on this issue, because they were 'called on to exercise a pre-eminently political judgment'. ${ }^{64}$ On the second issue, however, no such deference was deemed appropriate. 'If the right [Art. 5] is to be meaningful, the judges must be intended to do more than simply rubber-stamp the decisions taken by ministers and Parliament'. ${ }^{65}$ In this regard, the Belmarsh decision replicates the 'cocktail of robustness and timidity'66 that typifies the decisions of the European Court of Human Rights in this area. ${ }^{67}$

The House of Lords' decision in the Torture Evidence case follows a broadly similar pattern. The question before the House was whether SIAC could 'receive evidence which has or may have been procured by torture inflicted ... by officials of a foreign state without the complicity of the British authorities'. As a matter of principle, the question was met with what Lord Bingham called an 'emphatic negative'. ${ }^{68}$ The condemnation of torture was said to amount to a 'constitutional principle'. ${ }^{69}$ The equivocating approach of the Court of Appeal was rejected. The common law, Lord Bingham said, 'has regarded torture and its fruits with abhorrence for over 500 years, and that abhorrence is now shared by over 140 countries which have acceded to the Torture Convention. I am startled, even a little dismayed, at the suggestion (and the acceptance by the Court of Appeal majority) that this deeply-rooted tradition and an international obligation solemnly and explicitly undertaken can be overridden by a statute and a procedural rule which make no mention of torture at all. ${ }^{70}$ Having settled the issue of principle, the judges considered the appropriate standard of proof with which this principle ought to be applied by SIAC, at which point a more pragmatic, conciliatory note enters the judgment. The majority's preferred test was that evidence should be excluded if, on the balance of probabilities, it had been obtained by torture. If

62 For a discussion of Lord Hoffmann's change of position from Rehman to Belmarsh see T. Poole, 'Harnessing the Power of the Past? Lord Hoffmann and the Belmarsh Detainees Case' (2005) 32 Journal of Law \& Society 534.

${ }^{63}$ See also A. Tomkins, 'Readings of $A$ v Secretary of State for the Home Department' [2005] PL 259.

${ }^{64}$ A v Secretary of State for the Home Department [2004] UKHL 56, [29].

65 ibid [164] (per L Rodger).

${ }^{66} \mathrm{n} 30$ above, 272.

${ }^{67}$ See, e.g., Lawless v Ireland, 3 Eur. Ct HR (ser. A) (1960-61); Brogan and Others v United Kingdom, 145-B Eur. Ct HR (Ser. A) (1988); Brannigan and McBride v United Kingdom, 258 Eur. Ct HR (ser. A) (1993); Aksoy v Turkey, 23 Eur. HR Rep. 553 (Dec. 18, 1996); Sakik and Others v Turkey (1977) ECHR (Nov. 26, 1997); Demir and Others v Turkey (12380/93) (1998) ECHR 88 (Sept. 2, 1998). See also the European Commission decision in the Greece v United Kingdom, 1958-1959 YB Eur. Conv. On HR 174.

68 A v Secretary of State for the Home Department [2005] UKHL 71, [1].

69 ibid [12].

70 ibid [51] (per L Bingham). 
SIAC were left in any doubt about the provenance of evidence, it should be admitted. ${ }^{71}$ (The minority favoured a more demanding test: SIAC should exclude evidence if there is a 'real risk' that it may have been obtained by torture. ${ }^{72}$ ) In establishing this test, the majority judges reveal a disinclination towards completely closing the space (outside the law?) that had been left open by the Court of Appeal. Lord Nicholls said that 'in cases such as these the government cannot be expected to closes its eyes to this information at the price of endangering the lives of its own citizens. Moral repugnance to torture does not require this.' Lord Hope argued in similar vein that:

it would be unrealistic to expect SIAC to demand that each piece of info be traced back to its ultimate source ... Too often we have seen how the lives of innocent victims and their families are torn apart by terrorist outrages. Our revulsion against torture ... must not be allowed to create an insuperable barrier for those who are doing their honest best to protect us. A balance must be struck between what we would like to achieve and what can actually be achieved in the real world[.] $]^{73}$

The similarities between the Belmarsh and Torture cases should not be overplayed. The decisions are different in terms of their structure. While Belmarsh is marked by a Strasbourg-style proportionality or balancing test, the Torture case centrally involves the interpretation of the common law's prohibition on torture. In the former case, then, the balancing takes place on the surface of the judgment, whereas in the latter the balancing occurs later on in the judgment, when discussing the way in which the principle ought to be applied by SIAC. The decisions are also different in terms of what they are prepared to concede. In Belmarsh, 'first-order' questions concerning the declaration of a state of emergency are conceded and 'second-order' questions relating to proportionality and nondiscrimination are more strictly reviewed. In the Torture case, a strong statement of principle is juxtaposed with a more nuanced (and equivocating) approach to its practical application. But what these cases share is far more significant than what distinguishes them. While there are significant elements of accommodation in both decisions - a point to which I return - both cases display a spirit of judicial independence and a concomitant willingness to question at least some aspects of government counter-terrorist policy that is almost entirely absent from the line of 'accommodation' cases previously discussed. ${ }^{74}$

Two recent cases concerning control order provisions established under the Prevention of Terrorism Act 2005 also belong to this line of decisions. In $M B$, the Court of Appeal discussed the basis on which the courts would review the Home

\footnotetext{
71 ibid [118] (per L Hope).

${ }^{72}$ See in particular the judgments of Lords Bingham and Hoffmann.

73 n 68 above, [100] \& [119].

74 S. Shah, 'The UK's Anti-Terror Legislation and the House of Lords: The Battle Continues' (2006) 6 HRLR.
} 
Secretary's decision to make (non-derogating) control orders. There are two necessary elements, it was said, to the Home Secretary's decision. The first reasonable suspicion that the controlled person is or has been involved in terrorist-related activity - is 'an objective question of fact' which it is appropriate for the court to subject to real scrutiny. The second - whether it is necessary, in order to protect the public, to make the order - involves a value judgement in relation to which 'a degree of deference must be paid'. Notwithstanding this last observation, Lord Phillips insisted that 'there will be scope for the court to give intense scrutiny' to each control order. 'Some obligations may be particularly onerous or intrusive and, in such cases, the court should explore alternative means of achieving the same result. 75 The adoption here of the vocabulary of proportionality signals an intent not to allow deviation from normal standards of review. In JJ, the Court of Appeal upheld a decision to quash control orders on the ground that the conditions imposed on the claimants (including house arrest for 18 hours per day) were so severe as to amount to a deprivation of liberty under Art. 5 of the Convention. ${ }^{76}$ Sullivan J (the judge at first instance) said that, in the absence of a derogation order, the claimants were 'entitled to the full protection of Art 5, and there is no justification for any attempt to water down that protection in response to the threat of terrorism. ${ }^{77}$

The cases in the line starting with the House of Lords' decision in Belmarsh share display common themes. First, government claims that the times we inhabit call for special rules are met with judicial scepticism. At the level of principle, these cases tend to emphasise the need to adhere to accepted standards and principles. The government's argument, accepted in cases like Rehman, that adhering to normal standards in the current climate will amount to a threat to security and stability is inverted: the 'real threat to the life of the nation ... comes not from terrorism but from laws such as these. ${ }^{78}$ But these cases also contain an additional layer, since traces of deference are still to be found within them. (Recall, for instance, the majority's treatment of the declaration of emergency issue in Belmarsh, or the Court of Appeal's approach to the supervision of control orders in MB.) There is often, as the Torture case illustrates, a discontinuity between the clear restatements of principle that typifies these cases, and the more pragmatic and conciliatory way in which subordinate issues and questions of detail are handled. ${ }^{79}$ The presence of these undertones means that these decisions can best be understood in terms of the 'soft' variant of the 'Business as Usual' model identified by Gross and Ní Aoláin.

\footnotetext{
75 Secretary of State for the Home Department v MB [2006] EWCA Civ 1140, [57-65].

76 Secretary of State for the Home Department $\mathrm{v} J J$ and others [2006] EWCA Civ 1141.

77 Secretary of State for the Home Department v JJ and others [2006] EWHC 1623 (Admin), [43].

78 n 68 above, [97] (per L Hoffmann).

${ }^{79}$ Cf Hamdi v Rumsfeld 124 S. Ct 2633 (2004).
} 


\section{TERRORISM AND THE 'GOVERNMENT OF RISK'}

One dimension of argument in the cases works in a revealing register. Cases involving terrorist suspects often raise intricate questions involving matters of risk and secrecy. These matters have a direct bearing on the way courts handle questions of deference, which I explore in this section.

The fact that arguments about risk play a significant role in the government's defence of its counter-terrorist strategy before the courts is unsurprising. ${ }^{80} \mathrm{We}$ inhabit a society marked by the political salience of risk. ${ }^{81}$ While some doubt the more extreme formulations of the 'risk society' thesis, ${ }^{82}$ risk has certainly become an 'organising principle' 83 in both private and public spheres, and a central concept in thinking about law and society. ${ }^{84}$ Regulation scholars have gravitated towards the study of this new 'government of risk'. ${ }^{85}$ Black observes, for instance, that risk is fast becoming the central organising principle in regulation and public service delivery. ${ }^{.} 6$ Public administration, she continues, now operates according to a 'new public risk management' paradigm, examples of which include the Treasuryinitiated Hampton Report ${ }^{87}$ and the Better Regulation Executive. ${ }^{88}$ Other public lawyers have followed suit. Fisher has urged administrative lawyers to start thinking seriously about the implications of the rise of the new 'risk commonwealth' for their discipline. ${ }^{89}$ There is now some indication that human rights lawyers are beginning to take interest in the implications of a new governmental culture that speaks increasingly in the language of risk. ${ }^{90}$

The language of risk is prominent in the terrorism debate. Ours might be an age of rights, but it is also a time preoccupied by feelings of insecurity. Furedi

${ }^{80}$ Although, at the political level, the government tends to deploy a different language in order to justify its policy choices in this context: that is, by reference to the enormity of the threat posed by terrorists.

81 See, e.g., U. Beck, Risk Society: Towards a New Modernity (London: Sage, 1992); M. Douglas and A. Wildavsky, Risk and Culture (Berkeley and Los Angeles: University of California Press, 1983).

82 See, e.g., Russell Hardin, Trust (Polity, 2006), 28: 'the thesis of increasing risk in our lives, even if we count only those risks that others (and nature) impose on us, is implausible.' See also C. Hood, H. Rothstein and R. Baldwin, The Government of Risk (Oxford: OUP, 2004) 171: 'there is no such thing as risk society, only different risk regulation regimes.'

83 M. Power, The Risk. Management of Everything: Retbinking the Politics of Uncertainty (London: Demos, 2004) 48.

84 See, e.g., A. Giddens, 'Risk and Reponsibility' (1999) 62 MLR 1. See also D. Chalmers, 'Risk, Anxiety and the European Mediation of the Politics of Life' (2005) 30 European Law Review 649, arguing that the EU is transforming, and being transformed by, the government of risk.

${ }^{85}$ See, e.g., Hood $e t$ al., n 82 above. Risk has also been studied extensively by criminologists: see, e.g., B. Hudson, Justice in the Risk. Society (London: Sage, 2003); D. Garland and R. Sparks, 'Criminology, Social Theory and the Challenge of Our Times' (2000) 40 British Journal of Criminology 189.

86 J. Black, 'The Emergence of Risk-Based Regulation and the New Public Management in the United Kingdom' [2005] PL 512, 512.

87 Philip Hampton, Reducing Administrative Burdens: Effective Inspection and Enforcement, Final Report (London, 2005) ("Hampton Report").

${ }^{88} \mathrm{~J}$. Black, 'Tensions in the Regulatory State' [2007] PL 58, 67. But note that the salient 'risk' in risk-based regulation tends often to be institutional risk, not societal risks per se.

${ }^{89}$ E. Fisher, 'The Rise of The Risk Commonwealth and the Challenge to Administrative Law' [2003] PL 455.

${ }^{90}$ See, e.g., T. Murphy and N. Whitty, 'Risk and Human Rights: Ending Slopping Out in a Scottish Prison' in J. Morison, K. McEvoy and G. Anthony (eds.), Judges, Transition and Human Rights Cultures (Oxford: OUP, 2006). 
argues that fear, whose defining feature is 'the belief that humanity is confronted by powerful destructive forces that threaten our everyday existence', has become 'a powerful force that dominates the public imagination.' The 'politics of fear' that result ensure that 'political disagreements are often over which risk the public should worry about the most. ${ }^{91}$ Shklar once argued that the human rights consciousness that developed after World War II was prompted by a 'liberalism of fear'. ${ }^{22}$ The necessity of a moral law, that is to say, was sustained no longer by belief in reason but by the memory of horror. ${ }^{93}$ Extending Shklar's point, Hudson argues that a 'new liberalism of fear' has 'gripped western nations' in more recent times, this time a fear of strangers from both within their own borders. This climate gives rise to a 'politics of safety' in which rights 'to fair trial, rights to privacy, rights to proportionate penalties, rights to asylum and free movement of peoples are being curtailed because of fear of crime, fear of terrorism, fear of dilution of cultural identity, and fear of economic pressures. ${ }^{94}$ By focussing on the likelihood that certain dangers may eventuate at some point, the language of risk responds to this situation and imposes a framework that enables such fears can be articulated and 'managed'. Risk management, Black observes, brings to the conduct of public administration a sense of 'strategy and control'. This illusion of mastery provides a measure of security to a worried public while offering a useful legitimating device for the government (or other agency) deploying it. ${ }^{95}$

The idea of risk should be distinguished from the notion of harm. In ordinary language we use 'risk' as a synonym for danger or peril, but in the insurance context risk relates not to an event that might occur in reality but rather to a specific way of treating certain events. 'As a technology of risk', Ewald argues, insurance is first and foremost a schema of rationality, a way of breaking down, rearranging, ordering certain elements of reality. ${ }^{96}$ Whereas accidents are natural phenomena, risk is a category of understanding according to which certain real-world events are conceived in a particular way. Risk represents a 'certain type of rationality: one formalized by the calculus of probabilities. ${ }^{97}$ The insurer does not passively register the existence of risks, but produces them: 'he makes risks appear

91 See, e.g., F. Furedi, Politics of Fear (London: Continuum Press, 2005) 130-1.

${ }^{2}$ J. Shklar, 'The Liberalism of Fear' in S. Hoffman (ed.), Political Thought and Political Thinkers (Chicago: University of Chicago Press, 1998): the liberalism of fear 'does not to be sure offer a summum bonum toward which all political agents should strive, but it certainly does begin with a summum malum, which all of us know and would avoid if only we could. That evil is cruelty and the fear it inspires, and the very fear of fear itself.'

93 See further M. Ignatieff, Human Rights as Politics and Idolatry (Princeton: Princeton University Press, 2001), 80-1. Cf I. Berlin, 'European Unity and Its Vicissitudes' in The Crooked Timber of Humanity (London: Chatto and Windus, 1991), 204: 'Because these rules of natural law were flouted, we have been forced to become conscious of them.'

${ }^{94}$ Hudson, n 85 above, 221.

95 n 86 above, 519 .

${ }^{96}$ F. Ewald, 'Insurance and Risk' in G. Burchell, C. Gordon and P. Miller (eds.), The Foucault Effect: Studies in Governmentality (Chicago: University of Chicago Press, 1991) 199 (italics added).

97 ibid 199. 
where each person had hitherto felt obliged to submit resignedly to the flows of fortune. ${ }^{98}$

It is characteristic of insurance that it constitutes a certain type of objectivity, giving certain familiar events a kind of reality which alters their nature. By objectivizing certain events as risks, insurance can invert their meanings: it can make what was previously an obstacle into a possibility. ${ }^{99}$

In this sense, risk and premonitions of catastrophe are natural bedfellows. Pointing to the political potential of catastrophes, Beck argues that the risk society is adept at accessing the social and psychological resources of a political community that feels that it faces grave danger. 'Averting and managing these [catastrophes] can include the reorganization of power and authority. Risk society is a catastrophic society. In it the exceptional conditions threatens to become the norm.' ${ }^{100}$ Risk management can also be said to be orientated towards the future. 'In the risk society, the past loses the power to determine the present. Its place is taken by the future, thus, something non-existent, invented, fictive as the "cause" of current experience and action.' ${ }^{101}$

What typifies risk analysis in the terrorist context is the projection of extreme (probably exaggerated) fears - a 'negative image of utopia' - into the future on the basis of a few isolated but undeniably real events, the very strikingness of which their almost 'hyper-real' quality ${ }^{102}$ - tends to have a distorting effect. ${ }^{103}$ As Gross and Ní Aoláin observe, we know that 'panic, fear, hatred, and similar emotions' can colour 'our risk assessment in times of crisis and create a strong tilt toward putting undue emphasis on certain potential risks. ${ }^{104}$ In technical terms, risk analysis in the terrorist context is subject both to what social scientists call the availability heuristic (where people assess the magnitude of risks by asking whether examples readily come to mind; if they can easily think of such examples, they are far more likely to be frightened than if they cannot ${ }^{105}$ ) and to probability neglect (where people focus on the goodness and badness of the outcome in question, and pay too little attention to the probability that a good or bad outcome will

\footnotetext{
98 ibid 200.

99 ibid.

${ }^{100}$ Beck, n 81 above, 24. See also ibid 78-9: 'Hence they possess on the one hand the pretense of normality, and on the other, the enabling power of catastrophes, which can quite well achieve and exceed the political significance of revolutions. The risk society is thus not a revolutionary society, but more than that, a catastrophic society. In it the state of emergency threatens to become the normal state.'

101 ibid. 34.

102 For the discussion of the events of September $11^{\text {th }}$ as a spectacle, see J. Baudrillard, The Spirit of Terrorism (London: Verso, trans. C. Turner, 2003).

${ }^{103}$ Frank Furedi argues, however, that the politics of terrorism is but another manifestation of a much more general 'fatalistic sensibility', in part a product of manipulation by politicians, which 'disposes the public to feel uncomfortable about managing uncertainty': see n 91 above, 123

104 n 30 above, 105.

105 See A. Tversky and D. Kahneman, 'Judgment under Uncertainty' in D. Kahneman, P. Slovic and A. Tversky (eds.), Judgment under Uncertainty: Heuristics and Biases (Cambridge: CUP, 1982) 11-14.
} 
occur $\left.{ }^{106}\right)$. Studies show that people will pay a significant amount to avoid a small probability of a hazard that is emotionally gripping. As Sunstein elaborates, 'risks can suddenly come "on-screen", making people believe that where they once were "safe", they are now "unsafe".' Once people feel 'unsafe' about one risk, they are more likely to feel the same way about others: consider the situation in the United States, where the September 11 th attacks 'have elevated people's concern about many mortality risks, not simply those from terrorism.' 107

Douglas and Wildavsky's observation that 'we do not know the risks we face, but must act as if we do' contains two distinct dimensions. First, 'we do not know the risks we face'. Future events being inescapably uncertain, it might be said that there is room for reasonable disagreement about the likelihood and magnitude of conceivable risks. 'Every interested party attempts to defend itself with risk definitions, and in this way to ward off risks which could affect is pocketbook. ${ }^{108}$ One aspect of the political discourse of risk thus relates to its potential to frame political debate and so to dominate the political agenda. 'Since it is not possible to say everything at once, or with equal emphasis, something has to be slighted. Some sort of risk has to be hidden. ${ }^{109}$ Risks are selected, and so represent or reflect social or political choices about which hazards we should foreground and which we should relegate: 'the framing of the regulatory task in terms of risk has the potential to have more than a rhetorical effect: it imports particular conceptions of the problem at hand, and leads to the framing of a solution in a particular way." 110 The discourse of risk thus enables a government to impose a certain image of the future which can dominate or capture the contemporary political agenda.

The second part of the phrase - 'but we must act as if we do' - suggests that risk analysis is associated with expertise. Beck claims that the government of risk evokes "the possibility of objectively and obligatorily determining hazards in a specialized fashion and through expert authority. Science "determines risks" and the population "perceives risks".'111 The language of risk analysis, management and control brings with it a call for agencies capable of performing those functions, a demand that entails either the creation of new agencies with adequate expertise (or access thereto) or the redefinition of existing agencies along riskbased lines. ${ }^{112}$ In the terrorism context, the symbiosis of risk and expertise transforms a contest between 'players' mired in similar conditions of uncertainty into a game played out on different levels of uncertainty and ignorance. ${ }^{113}$

106 See, e.g., C.R. Sunstein, 'Probability Neglect: Emotions, Worst Cases, and the Law' (2002) 112 Yale LJ 61.

107 C. Sunstein, Laws of Fear: Beyond the Precautionary Principle (Cambridge: CUP, 2005).

108 Beck, n 81 above, 31 .

${ }^{109}$ Douglas and Wildavsky, $\mathrm{n} 81$ above, 27.

$110 \mathrm{n} 86$ above, 519.

111 Beck, n 81 above n. 81, 57.

112 On which see, e.g., $\mathrm{n} 88$ above.

113 Some go further. Robert Castel (in 'From Dangerousness to Risk' in Burchell et al, n 96 above, 289) argues that risk analysis represents a 'new witch-hunt': 'a vast hygienist utopia plays on the alternate registers of fear and security, introducing a delirium of rationality, an absolute reign of calculative reason 
Although we all operate in the face of an inscrutable future, only the government has access to intelligence information on the basis of which an informed assessment of risk can be based. This privileged access to superior resources is carefully guarded: partial information is released, and only then in a time and in a manner of the government's choosing. ${ }^{114}$ Feldman accuses the British government of using risk to help foster a climate of panic in relation to the terrorist threat. ${ }^{115}$ Marginal advantage generates extraordinary inequalities in power.

\section{RISK IN THE CASES}

Governments use risk as a central part of the argument that only they are in a position adequately to manage the threat of 'international terrorism'. Framing the issue in this way lends itself to a way of thinking in which expediency becomes the sole measure of success. Before the courts, risk arguments tend to take the following form. The threat posed by terrorism means that we live in a situation in which there is a high risk that terrible things might happen. While no one knows precisely when these events might materialize and with what frequency, the government is in a privileged position to estimate it. Only the government is privy to the necessary intelligence resources on the basis of which the best course of action can be identified. For the same reason, only the government is in a position to work out how to manage the risk. And the very gravity of the risks evoked (or hinted at) by government is designed to underscore a position in which risk management and expediency become watchwords.

Unpacked in this way, the potential for arguments from risk to militate against court intervention is plain. First, courts are in no position to act as assessors of risk since this course of action would demand access to intelligence material and expertise that the courts do not have and arguably cannot possess. Second, the imperialism of the language of risk and expediency seems to allow little room for the sort of values - due process, legal accountability, human rights and the like - that the court might want to inject into the process. Third, a stark reminder of the cost of getting things wrong is often sufficient to dissuade a court otherwise inclined to take a more interventionist line.

and a no less absolute happiness for a life to which nothing happens. This hyper-rationalism is at the same time a thoroughgoing pessimism, in that it pretends to eradicate risk as though one were pulling up weeds.'

114 See T.C. Ellington, 'Won't Get Fooled Again: The Paranoid Style of the Nation State' (2003) 38 Govt \& Opp 436.

115 Feldman, n 35 above, 379: 'Where terrorism is concerned, the people who assess the risk are those who claim to have the risk are those who claim to have a monopoly over the information needed to assess it, and they are also people who have most to gain in terms of power and resources from any government or legislative response: namely, the police and the secret service.' 
The problem facing the court is compounded by the paucity of material on which the court might make its own assessment of risk. Not only is this a result of a situation in which the behaviour of terrorists (and would-be terrorists) is unpredictable. (For that issue besets government assessments of risk as much as judicial ones.) It is also a function of the fact that at least some of the (more important?) material upon which the executive assesses risk in this context constitutes classified information ('closed material') about which it always hard and sometimes impossible for the court to gain access. Provisions of ATCSA 2001 and now the Prevention of Terrorism Act 2005 do allow for the appointment of 'special advocates' who may have access to 'closed material' to act in the interests of suspected terrorist (in closed court proceedings). 116 Despite the availability of this mechanism, secrecy - and what it entails for judicial supervision - is a persistent theme. Simpson has suggested that normal public law principles have 'nothing to contribute' within the national security context precisely because of the veil of secrecy that operates there: in the 'conflict between secrecy and the rule of law secrecy wins'. 117 The twin issues of (exceptional) risk and limited (secret) knowledge may be said to represent, then, 'conditions of uncertainty' in which courts in terrorist cases must operate.

The way in which risk operates to frame the political debate also demarcates lines and limits of responsibility. Risk sketches (in Pascal's phrase) a 'geometry of hazard' that aims to control the apportionment of blame.118 'In so far as risk based frameworks are defining what level of risks are tolerable, they are attempting to define which risks should be politically acceptable, and which should not, and in turn which the regulator should be blamed for, and which it should not. Risk and blame have long been associated." 119 Risk management shapes the political and administrative environment in which an agency operates, typically seeking to draw lines between those risks over which the agency assumes responsibility and those over which it does not. Where courts emphasise the high costs of making the wrong decision, and use this as a basis for deferring to the executive, they are saying that the matter is one beyond their control and responsibility. By contrast, the more courts engage in the scrutiny of government risk assessments in this context, the more they accept a measure of responsibility for the conduct of counter-terrorist policy - and thus open themselves up to more blame should things go wrong.

\footnotetext{
116 See, e.g., R v H [2004] UKHL 3. The special advocate system was adopted (in the Special Immigration Appeals Commission Act 1997 and rule 7 of the SIAC (Procedure) Rules 1998 (SI 1998/1881) following the ECtHR ruling in Chabal v UK [1996] ECHR 54.

117 n 5 above, 421. See also Dyzenhaus, n 12 above, 149-55.

118 See Ewald, n 96 above, 200.
} 


\section{LEGAL RESPONSES TO 'CONDITIONS OF UNCERTAINTY’}

Faced with these conditions of uncertainty, courts have two choices: to embrace arguments from risk, a position which suits the accommodation strategy and entails deference to government, or to challenge such arguments, which is consonant with the 'Business as Usual' approach.

\section{EMBRACING RISK}

Judges who accommodate executive claims about the need for crisis powers often draw uncritically on risk-based arguments. For instance, Lord Hoffmann's reminder in Rehman 'that in matters of national security, the cost of failure can be high' and that this failure may have 'serious potential results' for the community provided the basis for a highly deferential position. Laws LJ made extensive use of the language of risk in his judgment in the Torture case. 'The prevention of risk', he said, 'may be a very powerful imperative; powerful enough, in reason, to justify the imposition of legal sanctions where there is no conventional proof that this or that has happened or will happen.' Must the minister, he asked, 'show that at least some facts, such as concrete links with a terrorist organisation, are proved against [the suspected terrorist] if the [detention] certificate is to be held lawful? ... I am clear that the answer to that question is No'. ${ }^{120}$ Similar themes appear in the decision of the House of Lords in Gillan. An assessment of the reasonableness of the stop and search authorisation, Lord Scott said, 'requires an assessment of the degree of seriousness of the terrorist threat to which the authorisation was a response. This latter assessment will in most cases require some knowledge of the intelligence material on which the police and the Home Secretary relied when making their own assessment of that threat'. ${ }^{121}$

It was a short step, in each of these cases, from the identification of the situation as one in which there was a risk of outcomes which, should they occur, might result in great harm, to the conclusion that judicial involvement in such matters should be kept to a minimum. In other words, the amount of harm that would occur if the risk materialized was considered so great as to make questions relating to the probability that that risk might occur and the costs of taking preventative measures all but irrelevant. The courts, in this mode, do nothing to halt the imperialist tendency of risk as it operates in the counter-terrorist context since the effect of these decisions is to render cases to which arguments about risk and secrecy relate in practice non-justiciable. Rather, by seconding the risk-related dimensions of the government's argument, they lend credence to the claim that we

$119 \mathrm{n} 88$ above, 68 .

120 n 51 above, $157-8$.

121 n 57 above, 62. Cf the position in the Divisional Court: 'We are however concerned with a threat greater than any that this country in general, and its capital city in particular, has ever faced except in time of war. Assistant Commissioner Veness and the Secretary of State used their powers after taking into account expert assessments of the threat posed by terrorist activity and the risk that this threat would become a reality in London.' 
inhabit something akin to the Habermasian 'security state' in which values aside from security-related expediency are otiose. ${ }^{122}$

The problem with this approach to risk is that it cedes everything to the government, effectively turning counter-terrorism policy into a no-go zone - or legal black hole - free from any real legal scrutiny. As many commentators including a number of senior judges - have observed, this outcome is problematic. Counter-terrorism laws have clear potential to impact negatively on particular civil liberties and human rights. But, because of the prolonged, infinite nature of the 'war against terrorism', they also have the potential to undermine the values and standards of 'normal' constitutionalism. ${ }^{123}$

\section{Presumption of Good Faith}

A related approach is for the courts to work from the presumption that the government is acting in good faith. Brooke LJ's response in Belmarsh is typical of this approach. Judges, he said, should 'put an appropriate degree of trust in the willingness and capacity of ministers and Parliament ... to satisfy themselves about the integrity and professionalism of the Security Service.'124 Similarly, Lord Bingham observed in Gillan that the House of Lords had 'what appear to be considered and informed evaluations of the terrorist threat on one side and effectively nothing save a measure of scepticism on the other. There is no basis on which the respondents' evidence can be rejected. This is not a question of deference but of "relative institutional competence".'125 At first instance, the claimants had declined the use of a special advocate, which would have allowed the Divisional Court to review the underlying intelligence material in closed session. As things stood, his Lordship said, the House had no basis from which to make its own assessment and so could not reasonably conclude that the response to the terrorist threat was disproportionate. ${ }^{126}$

On this approach, terrorist cases decided in conditions of uncertainty are not quite non-justiciable. Rather, it imposes a high threshold test that closely matches the approach of the English courts in the pre-HRA era. (Recall Lord Denning's dictum in exp Hosenball that, in national security cases, 'even natural justice must

122 According to Habermas, the 'security state' represents a 'transformation of the boundary conditions of constitutional freedom that occurs when a society produces so many security risks that it is able to protect institutional values only by consistently expanding its surveillance apparatus.' In this system, the exercise of power is unchecked as standards of instrumental effectiveness become the only standards by which policies are judged: J. Habermas, Between Facts and Norms (London: Polity, trans. W. Rehg, 1996), 433.

123 See, e.g., Gross, n 6 above.

124 n 51 above [87].

125 n 58 above [17].

126 ibid [64]. Cf the decision of the Israel Supreme Court in HC 4764/04 Physicians for Human Rights v The Commander of IDF Forces in the Gaza Strip [The Rafah Case] (2004) at para [9]: 'We do not review the wisdom of the decision to take military action. We review the legality of the military operations. As such, we presume that the operations in Rafah are necessary from a military standpoint.' 
take a back seat'. ${ }^{127}$ ) It is tempting to argue that this approach represents a pragmatic judicial response to the conditions of uncertainty. After all, courts lack information in this context and, besides, this is an area that has often been regarded as 'within the exclusive discretion of the Crown'. But there are good reasons why this approach is objectionable. It is at least arguable that judges in the business of reviewing governmental actions should work from a position of scepticism. ${ }^{128}$ The fact that terrorist cases tend to be particularly complex is not itself a ground for jettisoning this sceptical habit of mind. Second, recent and notso-recent practice counsels against allowing governments undue latitude in this area. 'Anti-terrorist law', after all, 'has resulted in some of the most serious abuse of human rights in the UK over the past 30 years, it has often undermined mechanisms of accountability, and has corrupted even those institutions otherwise protective of civil liberties.' ${ }^{129}$ Third, it is simply not acceptable for courts to 'abdicate their responsibility' (as Simon Brown LJ put it) to act as a 'guardian of human rights' when confronted with a situation in which important evidence is withheld from them. As I argue later, there are a number of ways in which this knowledge deficit can be reduced.

\section{CHALLENGING RISK}

Where judges choose to adopt a 'Business as Usual' approach in terrorist cases, issues of risk and secrecy pose more intransigent problems. Three ways of responding to the problems associated with these conditions of uncertainty are possible. First, courts can sidestep issues of risk and secrecy by casting doubt, for instance, on the quality of intelligence information. Alternatively, courts might ignore risk, reasserting instead the values of 'normal' constitutionalism. Finally, courts may face up to the argument from risk in directly assessing to extent to which the government's case can withstand critical scrutiny. These strategies will be discussed in turn.

\section{SIDESTEPPING RISK}

One option for a court inclined to adopt a 'Business as Usual' approach is to sidestep government arguments relating to risk and secrecy. This approach involves expressing scepticism about the accuracy of the intelligence upon which the government purports to rely. The point tends to be raised obliquely rather

\footnotetext{
${ }_{127}^{R} \mathrm{v}$ Secretary of State for the Home Department, exp Hosenball [1977] 3 All ER 452: 'There is a conflict between the interests of national security on the one hand and the freedom of the individual on the other. The balance between these two is not for a court of law. It is for the Home Secretary. He is the person entrusted by Parliament with the task.'

128 See further T. Poole, 'Legitimacy, Rights and Judicial Review' (2005) 25 OJLS 697.

129 N. Whitty, T. Murphy and S. Livingstone, Civil Liberties Law: The Human Rights Act Era (London: Butterworths, 2001), 111.
} 
than pressed directly. This strategy has been used on occasion in the cases. Lord Hoffmann passing reference in Belmarsh to 'the widespread scepticism which has attached to intelligence assessments since the fiasco over Iraqi weapons of mass destructive'130 is one example. Another is Lord Rodger's assertion in the same case that 'judicial memories are no shorter than those of the public and the public have not forgotten the faulty intelligence assessments' used in respect of Iraq. ${ }^{131}$

The attractiveness of this approach is that it allows judges subtly to cast doubt on the evidence underpinning government risk assessments without having to articulate either their own basis for scepticism or their alternative assessment of the risk. This approach may be said to recognize the limited capacity of the court in this area. It accepts, that is to say, that the court is not really in a position to substitute its own assessment of risks associated with terrorism for the government's own analysis. (Although Lord Hoffmann in his Belmarsh judgment, as we shall see, was prepared to do precisely that. The flimsiness of the judgment, in terms of the quality of the evidence it adduced if not as a rhetorical statement, perhaps underscores the need for a more considered approach. ${ }^{132}$ ) The problem with this approach stems from its very indirectness. As Feldman has argued, 'the legitimacy of the judiciary arises from ... the obligation to justify its decisions publicly by means of rational arguments [and] the requirement that the reasons be formulated with reference to objective, publicly accessible standards with legal authority derived from a source other than the opinions of an individual judge'. ${ }^{133}$ Judges have a duty of candour when it comes to articulating the bases for their decisions. ${ }^{134}$ Casting aspersions on the credibility of evidence is not a justifiable response to risk, then, since such an approach fails to satisfy the requirement of full, open and reasoned decision-making that is the touchstone of the judicial role.

\section{IGNORING RISK}

In other cases, judges have accepted as a matter of principle that the government needs to make certain primary decisions on the basis of risk assessments, but have countered the imperialist dimension of risk by using civil liberties and human rights concerns as a counterweight. Sullivan J's dictum in JJ (a control order case) is exemplary: 'The importance of protecting members of the public from the risk of terrorism is not in doubt, but the importance of that objective is not a reason for the court to be any less inclined to classify the obligations in these control orders as a deprive of, rather than a restriction upon, liberty.' ${ }^{135}$ Cases in other jurisdictions also illustrate this approach. The Israel Supreme Court in held in its Public Committee Against Torture in Israel v State of Israel decision that a series of interrogation techniques used on terrorist subjects were illegal. In reaching this

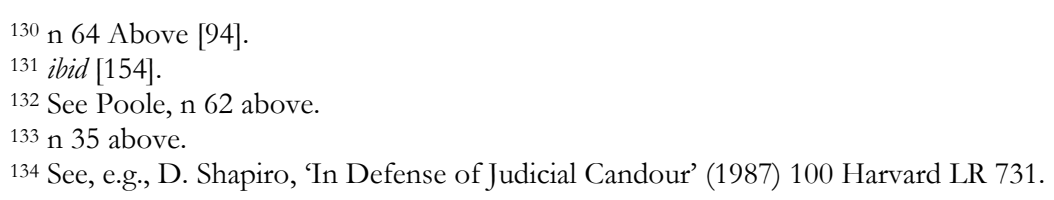


conclusion, the Court in effect cordoned itself off from the wider political context in which the case arose (combating terrorism in the occupied territories) and reasserted the primacy of normal legal values. President Barak, giving the judgment of the Court, proceeded from the (quite orthodox) administrative law assumption that 'the authority to conduct interrogations, like any administrative power, is designed for a specific purpose, and must be exercised in conformity with the basic principles of the democratic regime.' Prohibitions on torture, he said, are absolute: 'There are no exceptions to them and there is no room for balancing.' The interrogation techniques in question were unlawful, then, since they were not expressly authorized by the legislature and violated accepted standards of decency. ${ }^{136}$ The decision of United States Supreme Court in Hamdan v Rumsfeld that the military commission system established by an executive order ${ }^{137}$ was unlawful also relied on an orthodox methodology. ${ }^{138}$ Largely avoiding big questions of constitutional separation of powers and resting on the interpretation primarily of federal statutes, Justice Steven's opinion for the Court chose not to 'defer to the executive's reasonable interpretations of the relevant statutes, treaties, and customary international law on war.'139

This approach - circumvent risk-based arguments through the adherence to normal standards - finds considerable academic support. Gearty argues that we should be sceptical even of the way governments use the nomenclature of 'terrorist' and 'terrorism', and insists that courts (and others) must reassert in the face of arguments from risk and expediency the primacy of civil liberties and the normal values that attach to the investigation and prosecution of crime. ${ }^{140}$ This strategy has its attractions, not least for those concerned that normal constitutional standards are not watered down during times of crisis, whether real or purported. It represents a somewhat more direct approach to risk than the 'side-stepping' approach since it insists that civil liberties and human rights are given more weight in the risk assessment equation. In risk analysis terms, advocates of this approach argue that taking liberty concerns seriously neither makes terrorist attacks (significantly) more likely, ${ }^{141}$ nor has any effect on the amount of harm that might

\footnotetext{
$135 \mathrm{n} 136$ above [43].

136 HC 5100/94, Public Committee Against Torture in Israel v The State of Israel 53(4) PD. See also, e.g., Suresh v Canada (Minister of Citizenship and Immigration) [2002] 1 S.C.R. 3, at paras. 3-4: 'On the one hand stands the manifest evil of terrorism and the random and arbitrary taking of innocent lives, ripping out in an everwidening spiral of loss and fear. Governments ... need the legal tools to effectively meet this challenge. On the other hand stands the need to ensure that those legal tools do not undermine values that are fundamental to our democratic society - liberty, the rule of law, and the principles of fundamental justice - values that lie at the heart of the Canadian constitutional order and the international instruments that Canada has signed. In the end it would be a Pyrrhic victory if terrorism were defeated at the cost of sacrificing our commitment to those values.'

${ }_{137}$ Military Order of Nov. 13, 2001: Detention, Treatment, and Trial of Certain Non-Citizens in the War Against Terrorism, 66 Fed. Reg. 57,833 (Nov. 16, 2001).

138 Hamdan v Rumsfeld 126 S. Ct. 2749 (2006).

${ }^{139} \mathrm{~J} . \mathrm{Ku}$ and J. Yoo, 'Hamdan $\mathrm{v}$ Rumsfeld: The Functional Case for Foreign Affairs Deference to the Executive Branch’ (2006) 23 Constitutional Commentary 101, 103.

140 n 7 above. See also n 16 above.

141 See Waldron, n 34 above.
} 
be suffered in the event of such an attack, but does effect the assessment of costs associated with taking preventative action.

Despite the obvious attractions of this approach to liberals and constitutional lawyers, there are reasons for doubting whether this strategy of ignoring risk will always be a sufficient way of responding to risk-based arguments. For a number of reasons, it is unsatisfactory for risk arguments to go unanswered. First, like the preceding approach, this strategy may also fall foul of the requirements of open and reasoned argument identified by Feldman as the basis for the legitimacy of judgments. Second, the resulting situation, in which court and government seem to be talking at cross-purposes, may add to the perception, prevalent in some quarters, that human rights discourse is ungrounded and artificial. ${ }^{142}$ Third, ignoring risk arguments leaves the government's arguments about risk and secrecy untouched. The failure to remove risk-based arguments from the field of play, so to speak, leads courts into taking covert positions of accommodation. These dynamics may be one of the main factors underlying the pattern that we observed in many of the 'Business as Usual' cases: namely, a discontinuity between the clear restatements of principle that define these cases, and the more pragmatic and conciliatory way in which subordinate issues and questions of detail are handled. The Torture case is illustrative. A bold restatement of an orthodox legal position here, the common law's strong and long-standing hostility to torture - segued into something altogether more equivocal - the majority's decision on the standard to be applied where evidence may have been obtained by torture overseas. Decisions of this sort, while praiseworthy for their rhetorical reinforcement of liberal values, are problematic. The outcome of these cases often fails to match the rhetorical statements that preceded them, leaving the decisions lacking internal coherence and disappointing on account of their failure to deliver on their early promise. ${ }^{143}$

\section{FACING UP TO RISK}

A final approach to the conditions of uncertainty that courts face in terrorist cases shares with the previous techniques - 'side-stepping' and 'ignoring' risk - a basic or presumptive scepticism about risk-based (and related) arguments. Under the former approach, it is sufficient to hint at the doubts that courts might hold about government evidence; while under the latter it is generally enough for courts to steer clear of such arguments altogether. The current approach, by contrast, is marked by a willingness to question (wherever possible) the evidential basis that underscores the government's risk assessment.

Judges have been prepared, on occasion, to question openly and directly riskbased arguments in court. In some cases, courts have inverted (or at least

142 See, e.g., the Editor of the Daily Mail Paul Dacre's evidence to the House of Lords Constitution Committee, Wed 7 March 2007.

143 The then Home Secretary Charles Clarke MP said in response to the ruling that the Law Lords 'held it was perfectly lawful for such information to be relied on operationally and also by the Home Secretary in 
substantially modified) the government's assessment of the risks associated with terrorism. Lord Hoffmann's judgment in Belmarsh is the clearest example of this sort in the domestic context. In essence, Lord Hoffmann was prepared to deny that the evidence supported the government's claim that the risk from terrorists was so great that it amounted to an 'emergency threatening the life of the nation'. (As I suggested earlier, the weakness of the judgment relates not to its basic stance, but to a lack of robustness in its handling of the evidence.) A similar approach is visible in the decision of the US Supreme Court in Hamdiv Rumsfeld. In her plurality judgment, Justice O'Connor said that 'the risk of erroneous deprivation of a citizen's liberty in the absence of sufficient process here is very real.' She continued: 'as critical as the Government's interest may be in detaining those who actually pose an immediate threat to the national security of the United States during ongoing international conflict, history and common sense teach us that an unchecked system of detention carries the threat to become a means for oppression and abuse of others who do not present that sort of threat.'144 At least in this part of the decision, the Court showed itself alert to the risks that are downplayed by the governmental in its argument about terrorism and risk, pressed even more forcefully in the US than in the UK.

In terrorist cases, governments tend to warn courts that too much judicial scrutiny amounts to what risk analysts call a 'Type II' error (i.e. an error on the side of risk, when one assumes that a situation is safe when it is not). ${ }^{145}$ The courts should be careful, the argument goes, not to assume that the situation is safe when it is not (or might not be). The response of Lord Hoffmann in Belmarsh and the Supreme Court in Hamdi is almost to invert this equation. The government, they say, in arguing that its counter-terrorist policies should be largely immune from legal oversight, commits a 'Type I' error (i.e. an error on the side of caution, when one assumes that a situation is risky when it is not). Two points are being made by this inversion. First, that the government may well be working on the assumption that the situation is more dangerous than it really is. Second, that it is the duty of the court to expose the costs, both in terms of the civil liberties of individuals and the potential damage to the normal constitutional framework, that are otherwise hidden by this overreaction. ${ }^{146}$

This questioning approach to government risk-based arguments opens the door to further scrutiny of counter-terrorism policy. In $M v$ Secretary of State for the Home Department, for instance, the Court of Appeal upheld the decision of the Special Immigration Appeals Commission (SIAC) to overturn the Secretary of

making decisions'. Thus 'the exclusion of evidence obtained by torture ... will not change, weaken or detract from our ability to fight terrorism.' (The Guardian, 13 December 2005.)

144 n 79 above.

145 See, e.g., Hood et al., n 82 above, 181.

146 See, e.g., n 79 above, at 2641 (O'Connor, J.): 'We recognize that the national security underpinnings of the "war on terror", although crucially important, are broad and malleable. As the Government concedes, "given its unconventional nature, the current conflict is unlikely to end with a formal cease-fire agreement" ... If the Government does not consider this unconventional war won for two generations, and if it maintains during that time that Hamdi might, if released, rejoin forces fighting against the United States, then the position it has taken ... suggests that Hamdi's detention could last for the rest of his life.' 
State's decision to issue a deportation order under provisions of ATCSA 2001 against a Libyan national suspected of having connections with terrorist organisations. The Court of Appeal accepted that SIAC's method of 'submitting all the evidence to a close and penetrating analysis' was correct. 'While the need for society to protect itself against acts of terrorism today is self evident, it remains of the greatest importance that, in a society which upholds the rule of law, if a person is detained as " $\mathrm{M}$ " was detained, that individual should have access to an independent tribunal or court which can adjudicate upon the question of whether the detention is lawful or not. If it is not lawful, then he has to be released. ${ }^{147}$ Likewise, in the recent Abu Qatada case, SIAC held that the Home Secretary's submissions that the Commission 'should tread lightly and recognise' that it was poorly equipped to review the assessments and decisions in the field of diplomatic relations 'wholly unpersuasive'. Ouseley J said that it was for SIAC itself to 'decide how much weight to give to what [the Home Secretary] says, forming its own view of his evidence. ${ }^{148}$ Eschewing deference in this way, the Commission conducted a rigorous and independent analysis of the government's assessment of the risk that the applicant might suffer ill-treatment were he to be removed to Jordan under the conditions of a 'memorandum of understanding' between the UK and Jordan. (SIAC concluded, in the circumstances, that there was no real risk of ill-treatment.)

I said earlier that there is a close connection between risk-based assessments and the confidential nature of much of the material on which those assessments the basis are made. If the courts are to be in a position adequately to assess the lawfulness of government policy in this context, it is imperative that they obtain access to as much relevant material as possible. It is also necessary for courts to develop the wherewithal to be able to assess this material in a suitably critical manner. As we saw earlier, provisions have been made - originally at the prompting of the European Court of Human Rights ${ }^{149}$ - for the disclosure of 'closed' material before courts in proceedings in camera. But, judging from the confused state of the caselaw, more is needed. Two recent Canadian developments are interesting in this regard, since both deal with the problematic nexus between counter-terrorist policy and secret intelligence. The first is the Report of the Commission of Inquiry into the Actions of Canadian Officials in Relation to Maher Arar ('Arar Inquiry'). 150 Arar was a Canadian citizen, born in Syria, who was arrested and detained by US authorities in September 2002. He was then removed to Syria where he was imprisoned for nearly a year, tortured and held in inhumane and degrading conditions. He was returned to Canada after his release in October 2003. Arar was not charged with any offence in the US, Canada or Syria and there was no evidence to show that he had committed any offence or constituted a

147 M v Secretary of State for the Home Department [2004] EWCA Civ 324 [23] \& [34].

148 Abu Qatada v Secretary of State for the Home Department [2007] UKSIAC 15/2005 at [339].

149 Chabal v United Kingdom (1996) 23 EHRR 413.

150 Commission of Inquiry into the Actions of Canadian Officials in Relation to Maher Arar, Report of the Events Relating to Maber Arar (2006), 426: 'The most compelling reason for developing a robust review mechanism for the RCMP's national security activities is the lack of transparency that necessarily accompanies all national security investigations.' 
security threat. Concerns about the way the Canadian government had dealt with US security agencies led to the instigation of a public inquiry. The Report was critical of official behaviour before, during and after Arar's imprisonment in Syria. ${ }^{151}$ It also made a series of recommendations for enhanced review and accountability mechanisms for agencies dealing with national security. ${ }^{152}$

Two aspects of the Report merit particular attention. The first relates to the way in which the Inquiry developed a process that enabled it to produce a thorough (and highly critical) report into an area marked by 'conditions of uncertainty'. As the Report observed, the Inquiry operated in a context in which much of the evidence could only be heard in closed proceedings and where '[e]veryone appearing in in camera proceedings had interests that were identical or similar to the Government's."153 Various methods were established in order to counteract these problems. ${ }^{154}$ Commission counsel were instructed to test the in camera evidence where necessary by means of cross-examination, whether or not the government agreed, since, as the Commissioner observed, 'when parties affected by the proceedings are not present to perform the cross-examination role, it is extremely helpful and even essential that there be an independent person able to do so.' ${ }^{155}$ The Inquiry was also assisted by the appointment of amici curiae. The aim was to appoint persons independent of the Govenrment, with extensive expertise in national security matters' to assist. Amici had access to all documents received, as well as to transcripts of entire in camera evidence. ${ }^{156}$ Further, the Inquiry also sought to prepare a summary of the in camera evidence that could be disclosed publicly, since it considered it important to make as much information as possible available to the public. ${ }^{157}$

A second noteworthy aspect of the Report relates to the misuse by government of classified information. The Inquiry noted two main forms of misuse. First, the Report concluded that 'Government of Canada officials intentionally released selected classified information about Mr Arar or his case to the media.' The purpose of so doing was to use 'the media to put a spin on [the] affair and unfairly damage' Arar's reputation. ${ }^{158}$ Several of the leaks were

\footnotetext{
151 See Arar Report, ch. 1 ('An Overview of My Findings').

152 See in particular Commission of Inquiry into the Actions of Canadian Officials in Relation to Maher Arar, A New Review Mechanism for the RCMP's National Security Activities (2006).

153 Arar Report, 291. The Report also noted that 'while the challenges underlying this process were unique for a public inquiry, an increasing number of judicial and administrative proceedings have had to address the same or similar issues in recent years.'

154 The Report also detailed several principles that guided the conduct of the Inquiry: 'thoroughness, expeditiousness, openness to the public, and fairness.' (at 282)

155 ibid, 292.

156 ibid, 293-4.

157 The Canadian Government responded to this aspect of the Inquiry by instituting Federal Court proceedings challenging the disclosure of some information the Inquiry considered could be made public. Wanting to avoid the considerable delay that would result should litigation occur, the Inquiry discontinued the approach of producing summaries of the in camera evidence, and decided to defer further rulings on this issue until after the hearing had been completed. The Government then withdrew its litigation and the Inquiry proceeded.

158 This is not an isolated occurrence. After the release from Guantanamo Bay, three British detainees (Shafiq Rasul, Asif Iqbal and Rhuhel Ahmed) were subject to false accusations. 'In the week after their
} 
inaccurate, unsupported by the intelligence information, and grossly unfair to $\mathrm{Mr}$ Arar. This pattern of behaviour was particularly egregious since, in this context, 'government authorities with access to classified or confidential information are in a position to sway public opinion by selectively divulging information to the media. ${ }^{159}$ Second, the Report was highly critical of the practice of government 'overclaiming' while the Inquiry was in progress. The Government had 'for over a year, asserted NSC [National Security Certificate] claims over a good deal of information that eventually was made public, either as a result of the Government's decision to re-redact certain documents ... or through this report.' This overclaiming occurred despite Government assurances that its initial NSC claims reflected its 'considered' position and would be directed at maximizing public disclosure. ${ }^{160}$

A second example is a case heard recently by the Supreme Court of Canada. Charkaoui v Canada ${ }^{161}$ concerned the Immigration and Refugee Protection Act (IRPA) 2001, which allowed ministers to issue a certificate of inadmissibility leading to the detention of a permanent resident or foreign national deemed to be a threat to national security. ${ }^{162}$ The certificate and detention were both subject to review by a judge, in a process that might deprive the person named in the certificate of some or all of the information on the basis of which the certificate was issued or the detention ordered. The case thus concerned, as McLachlin C.J. observed when delivering the judgment of the Court, a basic tension that lies at the heart of modern democratic governance between the imperative of security which may require government to act on information it cannot disclose - and the imperative of accountable constitutional governance. ${ }^{163}$

While the applicants challenged the provisions of the compatibility of the Act with the Canadian Charter of Rights and Freedoms on a number of grounds, the main focus of the judgment was whether the IRPA conformed with fair process protections associated with the right to life, liberty and security of the person guaranteed by section 7 of the Charter. In reviewing national security provisions under s. 7, the Court said that the 'bottom line' was that 'while administrative constraints associated with the context of national security may inform the analysis on whether a particular process is fundamentally unfair, security concerns cannot be used to excuse procedures that do not conform to fundamental justice'. ${ }^{164}$ It was held that, while judges under the IRPA were sufficiently independent and impartial, the scheme satisfied neither the requirement that the judge make a

release, the tabloid Sun newspaper published claims by a US Embassy spokesman, Lee McClenny, who said that they had, after all, trained at an al-Qaeda camp in 2000, notwithstanding the fact that MI5 had already proved that noen of them had left the United Kingdom that year.' See D. Rose, Guantanamo: America's War on Human Rights (London: Faber \& Faber, 2004) 130.

159 Arar Report, 255-7.

160 ibid., 302.

161 Charkaoui v Canada (Citizenship and Immigration), 2007 SCC 9.

162 Immigration and Refugee Protection Act, S.C. 2001, c. 27, ss. 33 \& 77-85.

163 n 161 above [1].

164 ibid [23]. See also $i d$. at [27]: 'The protection may not be as complete as in a case where national security constraints do not operate. But ... meaningful and substantial protection there must be.' 
decision based on the facts and the law nor the requirement that the named person be afforded an opportunity to meet the case put against him or her by being informed of that case and being allowed to question or counter it were not satisfied. ${ }^{165}$ In relation to the former, since a judge under the scheme does not have full inquisitorial powers and the certified person is not given full disclosure nor a right to participate in the proceedings, the result is that 'the designated judge, despite his or her best efforts to get all the relevant evidence, may be obliged perhaps unknowingly - to make the required decision based on only part of the relevant evidence.' ${ }^{166}$ This makes the judge feel 'a little bit like a fig leaf' in a process that remains uncomfortably ' $p$ seudo-inquisitorial'. ${ }^{167}$ In relation to the latter, the result of the certification scheme's 'constant preoccupation' with secrecy and confidentiality, 'the judge may be required to decide the case, wholly or in part, on the basis of information that the named person and his or her counsel never see. The person may know nothing of the case to meet, and although technically afforded an opportunity to be heard, may be left in a position of having no idea of what needs to be said.' 168

The Court noted that the IRPA scheme has no provision for 'special advocates' as used now in the $\mathrm{UK}^{169}$ and previously in Canada under procedures developed by the Security Intelligence Review Committee ${ }^{170}$ (the inspiration behind the ruling of the European Court in Chabal). It concluded that procedures in question failed to conform to principles of fundamental justice as embodied in s. 7 of the Canadian Charter: 'the secrecy required by the scheme denies the named person the opportunity to know the case put against him or her, and hence to challenge the government's case. This, in turn, undermines the judge's ability to come to a decision based on all the relevant facts and law. Despite the best efforts of judges of the Federal Court to breathe judicial life into the IRPA procedure, it

\footnotetext{
165 ibid [31].

166 ibid [50].

167 ibid [51]. Indeed, the Court said that Federal judges asked to operate the scheme had 'expressed unease': $i d$. at [36].

168 ibid [55].

169 Special Immigration Appeals Commission Act 1997, s. 6; Rule 35 of the Special Immigration Appeals Commission (Procedure) Rules 2003, S.I. 2003/1034; Prevention of Terrorism Act 2005. See also House of Commons Constitutional Affairs Committee, Report on The Operation of the Special Immigration Appeals Commission (SLAC) and the Use of Special Advocates which noted at para. 52 three important disadvantages faced by special advocates: (1) once they have seen the confidential matter, they cannot, subject to narrow exceptions, take instructions from the appellant or the appellant's counsel; (2) they lack the resources of an ordinary legal team, for the purposes of conducting in secret a full defence; and (3) they have no power to call witnesses.

${ }_{170}$ Established under the Canadian Security Intelligence Service Act, S.C. 1984, c. 21. The SIRC counsel were instructed to cross-examine intelligence service witnesses 'with as much vigour as one would expect from the complainant's counsel'. After the ex parte portion of the hearing, the excluded person would be provided with a summary, which would include 'the gist of the evidence, without disclosing the national security information' The affected person and his/her counsel would then be allowed to ask their own questions, and to cross-examine on the basis of the summary. See SIRC Annual Report 1988-1989 (1989) at 64. For analysis, see M. Rankin, 'The Security Intelligence Review Committee: Reconciling National Security with Procedural Fairness' (1990) 3 CJALP 173. The SIRC counsel were instructed to crossexamine intelligence service witnesses 'with as much vigour as one would expect from the complainant's counsel'.
} 
fails to assure the fair hearing that s. 7 of the Charter requires before the state deprives a person of life, liberty or security of the person.. ${ }^{171}$ The Court thus issued a declaration that the procedure was inconsistent with the Charter and hence unlawful, suspended for one year from the date of the judgment in order to give Parliament time to amend the law'. ${ }^{172}$

These two Canadian sources reveal a sophisticated awareness of the importance of the connection between secrecy and risk in the national security/counter-terrorist context. As Commissioner O'Connor wrote in his Maher Arar Report, in 'legal and administrative proceedings where the Government makes NSC claims over some information, the single most important factor in trying to ensure public accountability and fairness is for the Government to limit, from the outset, the breadth of those claims to what is truly necessary.' 173 The point can be generalized. If courts are to perform a real role in scrutinising counter-terrorist policy, they must ensure that legal procedures designed to review the actions and decisions of government ministers are fit for the purpose and that as much evidence as possible is brought to light in these procedures. This may require courts to restate normal public law principles (as the 'ignoring risk' approach demands), and to delineate as in Charkaoui a 'bottom line' below which standards may not slip. This need not involve direct, hostile confrontation with the government: both Canadian examples are models of reasonableness and (at least rhetorical) restraint. It may also require courts (and other scrutiny bodies) to become more active in searching for evidence and more questioning of government when it does decide to withhold it. Courts must also begin to develop the capacity to assess such evidence. The thoroughness of the assessment of risk in Abu Qatada indicates perhaps that the (specially-constituted) SIAC has confidence in this regard. ${ }^{174}$ The use of amici curiae with national security experience in the Arar Inquiry indicates another possible way of addressing the 'knowledge deficit' that characterises this area.

\section{CONCLUSION: PEERING THROUGH THE GLASS DARKLY?}

Courts are increasingly called upon to review the decisions and actions of government officials charged with administering counter-terrorist laws and policies. The response of the domestic courts in these cases to date has been mixed. In some cases, courts have followed the traditional highly deferential

\footnotetext{
171 n 161 above [65]. The scheme also fell foul of the Charter in denying a prompt hearing to foreign nationals by imposing a 120-day embargo after confirmation of the certificate on applications for release: id. at [141].

172 ibid 139-140.

173 Arar Report, 304.

174 Critics of the decision argue that SIAC was misguided to share the government's confidence that the conditions specified in a memorandum of understanding will in practice be adhered to. See, e.g., C. Walker, 'The Treatment of Foreign Terrorist Suspects' (2007) 70 MLR 427, 441-50.
} 
approach towards the review of national security matters. In other cases, they have essayed a more robust approach and have sought to impose substantial limits to otherwise untrammelled executive power.

Whichever position the courts adopt, decision-making in the terrorist context takes place in an environment where arguments about risk abound and in which some of the evidence upon which assessments of risk are made are shrouded in secrecy. These 'conditions of uncertainty' form a central feature of this area of law, and prove particularly problematic for courts seeking to limit governmental power. At the conceptual level, risk imagines a 'geometry of hazard' - a seemingly rational framework for the articulation and management of (specified) hazards. At the practical level, risk management appears to entail the creation of a cadre of specialists capable of assessing and managing risk. When deployed in this context, both these aspects of risk seem designed to foreclose the possibility of substantial judicial scrutiny. And the 'closed' (secret) nature of much of the material on which terrorist risk assessments are ostensibly made unbalances the situation still further. When played out in the domain of the necessarily unknowable future, marginal advantages in terms of access and understanding to information relating to possible risks generate claims for enormous disparities in power.

When courts are faced with risk arguments, the duty to articulate a reasoned basis for their decisions - a duty which grounds the legitimacy of the judicial enterprise - is a complicating factor. There is a dissonance between the discourse of risk and that of law, one which those who make risk arguments in this context seek to exploit. Law is the voice of authority and talks generally about the present in terms of the past, whereas risk speaks the language of future possibilities. But, as we have seen, these difficulties need not be intractable. A variety of responses to risk are possible, as recent cases have shown. Of the two most plausible candidates - 'ignoring' risk in the furtherance of a human rights strategy and 'facing up to risk' by scrutinising the evidence underpinning risk assessments - the first is insufficient. Avoiding risk issues allows the government's risk assessments to hold the field, and often means that accommodating elements infiltrate judicial decisions. It also fuels the perception that human rights discourse is artificial and removed from strategic or 'real world' concerns. Courts in terrorist cases will always be forced to peer, as it were, through the glass darkly. While it may well be true that the provision of 'special' arrangements for the admission and hearing of evidence is at most a 'second-best' solution, courts are beginning to grapple with this predicament to good effect, as the two recent Canadian examples illustrate. Effective scrutiny in this context requires courts not only to reiterate 'normal' public law principles, but also to demand that as much evidence be adduced before them as possible, whether in special proceedings or otherwise, and to examine that evidence robustly, perhaps with the assistance of amici curiae with relevant expertise.

The development and maintenance of effective methods of scrutiny enables courts to contribute to the process of opening up governing security policies - and the claims relating to uncertainty and risk that often underpin them - to public 
discussion. Loader and Walker have recently made the case for the application of the principle of public reason 'to the institutional matrix for governing security', an addition which would require security measures to be subject to rigorous public scrutiny and deliberation 'in a process aimed at identifying which security claims can reasonably be said to be oriented to considerations of the common interest'. ${ }^{175}$ In the United States, Phillip Heymann has made similar calls for the public discussion of trade-offs between security and liberty that are proposed by the executive and for the assigning in that debate of at least some value to longestablished civil liberties. ${ }^{176}$ While courts have little security-related expertise, they do have institutional strengths which can prove valuable in this context. In particular, the detailed forensic method they deploy allows them to subject particular exercises of anti-terrorism laws to intense legal scrutiny, an approach which can prove effective in reducing excesses. In addition, the conservative or past-oriented nature of law has a potentially vital normalising role. By delving into its reservoir of inherited principles, the court can contribute to the delineation of the basic values that should orient public deliberation on security. Thus may the invocation of the apparent decency and solidity of the past provide, like Dante's Virgil, some guide to the uncertain paths of the future.

175 I. Loader and N. Walker, Civilizing Security (Cambridge: CUP, 2007) 228.

176 P. Heymann, Terrorism, Freedom, and Security (Cambridge, MA: MIT Press, 2003). On this issue, Heymann is critical of the Bush Administration's attempt to block the involvement of other branches of government in its security plans and its related strategy of concealment (ibid, 160). 